\title{
STUDI KUAT TEKAN \& SETTING TIME BETON DENGAN VARIASI DOSIS ADMIXTURE TIPE D
}

\author{
Arifien Nursandah 1), Dio Alif Hutama ${ }^{3)}$, Agus Komarudin' ${ }^{2}$, \\ 1) Prodi Teknik Sipil, Fakultas Teknik, Universitas Muhammadiyah Surabaya \\ JL. Sutorejo No. 59 Kota Surabaya, Jawa Timur, 61135 \\ E-mail: arifien.nursandah@gmail.com \\ 2) Prodi Teknik Sipil, Fakultas Teknik, Universitas Muhammadiyah Surabaya \\ JL. Sutorejo No. 59 Kota Surabaya, Jawa Timur, 61135 \\ E-mail: dioalifhutama@ft.um-surabaya.ac.id \\ 3) Prodi Teknik Sipil, Fakultas Teknik, Universitas Muhammadiyah Surabaya \\ JL. Sutorejo No. 59 Kota Surabaya, Jawa Timur, 61135 \\ E-mail: komar46321@gmail.com
}

\begin{abstract}
Various research and experiments in the field of concrete is done as an effort to improve the quality of concrete, One of them to improve the quality of concrete is added admixture type D-retarder. It is expected that the results of these experiments and experiments are able to answer the higher demands in the foundry implementation which sometimes takes a long time. The purpose of this study was to investigate the effect of Type D dosage admixture on moderate quality concrete $\mathrm{fc} 30$, the dose of this study was $0 \%, 0.35 \%, 0.75 \%, 1.10 \%$ of sementitious weight. The test used is a compressive strength to determine the quality of fc 30 while setting time to find the initial time of sett. which is used as parameter parameter does not occur cold joint. The result showed that experiment 1 as the parameter that is design without admixture type $\mathrm{D}-\mathrm{VZ}$, dose $0,00 \%$, compressive strength 28 days 33,13 Mpa, experiment 2 dose $0,35 \%$, compressive strength up $10 \%$ from experiment 1,3 dose experiments $0.75 \%$, a compressive strength rose $6 \%$ from experiment 1 , experiments 4 doses $1.10 \%$, a compressive strength down $4 \%$ from experiment 1 . As for the D-VZ admixture dosage and addition dose, concrete deceleration deceleration, D-VZ type non-admixture concrete parameter, 1 dose $0,00 \%$ experiment resulted in initial sett 127 minutes, 2 dose experiment $0.35 \%$, resulted in initial sett 267 minutes, experiment 3 dose $0.75 \%$, resulted in initial sett 933 minutes, experiment 4 dose $1.10 \%$, resulted in initial sett 2520 minutes. Expected from this research, can be used as a reference for Project Supervisor, Contractor, Readymix Supplier, especially for concrete over dose (= long concrete setting), which can be maintained with the reference of strong compressive strength achieved, so that the concrete loong setting on the structure is not in Demolish (= slash). And will be used as a handle if it requires deceleration concrete can be added admixture type D.
\end{abstract}

Keywords: Concrete, Strength, and Type D Admixture.

\begin{abstract}
Abstrak
Berbagai penelitian dan percobaan dibidang beton dilakukan sebagai upaya untuk meningkatkan kualitas beton, Salah satunya untuk peningkatan kualitas beton yaitu ditambahkan admixture tipe D-retarder. Diharapkan dari hasil penelitian dan percobaan tersebut mampu menjawab tuntutan yang semakin tinggi dalam pelaksanaan pengecoran yang terkadang membutuhkan waktu lama. Tujuan dari penelitian ini adalah untuk mengetahui pengaruh dosis admixture Tipe $D$ pada beton mutu moderat $\mathrm{fc} 30$, dosis penelitian ini adalah $0 \%, 0,35 \%, 0,75 \%, 1,10 \%$ dari berat sementitious. Uji yang dipakai adalah Uji Kuat tekan untuk mengetahui mutu fc30 MPa, sedangkan Setting time untuk mengetahui waktu inisial sett. yang dipakai sebagai parameter parameter tidak terjadi cold joint. Hasil penelitian menunjukan, percobaan 1 sebagai parameter yaitu desain tanpa admixture tipe $D$ - $V Z$, dosis $0,00 \%$, kuat tekan umur 28 hari menghasilkan kuat tekan 33,13 MPa, percobaan 2 dosis 0,35\%, menghasilkan kuat tekan 36,36 $\mathrm{MPa}$, percobaan 3 dosis $0,75 \%$, menghasilkan kuat tekan $35,10 \mathrm{MPa}$, percobaan 4 dosis 1,10\%, menghasilkan kuat tekan 31,67 MPa. Sedangkan untuk Pemakian dan Penambahan dosis admixture tipe D-VZ, terjadi perlambatan pengersasan beton, parameter beton non admixture tipe $D-V Z$, percobaan 1 dosis $0,00 \%$ menghasilkan initial sett 127 menit, percobaan 2 dosis $0,35 \%$, initial sett 127 menit 267 menit, percobaan 3 dosis 0,75\%, initial sett 933 menit, percobaan 4 dosis 1,10\%, initial sett 2520 menit. Yang diharapkan dari penelitian ini , bisa dijadikan referensi bagi Pengawas proyek, Kontraktor, Suplier Readymix, terutama untuk beton over dosis ( = beton long setting), mana yang boleh dipertahankan dengan acuan mutu kuat tekan tercapai, sehingga beton long setting pada struktur tidak di Demolish (= tebang). Dan akan bisa dijadikan pegangan jika membutuhkan perlambatan pengerasan beton maka beton bisa ditambahkan admixture tipe $D$.
\end{abstract}

Kata Kunci : Beton, Kuat tekan, dan Admixture Tipe D 


\section{Pendahuluan}

Semakin meningkatnya jumlah kebutuhan produksi beton dalam dunia konstruksi, mengakibatkan peningkatan kebutuhan material penyusun beton. Salah satu material penyusun beton adalah semen. Semen berfungsi sebagai bahan pengikat antar agregat dimana dalam penggunaannya sangat mutlak ada dalam setiap konstruksi beton. Semakin meningkatnya pemakaian semen, membuat semakin menipisnya ketersediaan bahan baku semen menuntut ditemukannya suatu bahan baru yang berfungsi untuk menggantikan peran semen atau yang bisa mengurangi pemakaian semen, hal tersebut bisa di capai jika kita menambahkan Admixture chemical (=bahan tambahan kimia dalam beton).

Bahan tambahan atau admixture tersebut adalah bahan tambahan yang ditambahkan kedalam campuran beton pada saat atau selama pencampuran yang berfungsi untuk memenuhi kecocokan beton untuk pekerjaan tertentu dalam hal mengubah sifat, menghemat biaya, menghemat waktu dan lain-lain.

Salah satu dari tujuh tipe bahan bahan tambah yang berfungsi Water Reducing and Retarter atau tipe D adalah admixture chemical yang bersifat ganda. Fungsi pertama adalah sebagai mampu mengurangi kadar air bebas, sedangkan fungsi yang kedua adalah untuk menghambat waktu pengikatan beton, hanya saja jika zat yang kedua ini over dosis maka yang terjadi adalah terjadinya long setting.

Dari kondisi tersebut maka diperlukan suatu penelitian untuk bisa dijadikan suatu referensi bagi Kontraktor, Konsultan , Management Konstruksi, ataupun bagi Readymix terkait langkah yang diambil kalau terjadi overdosis (kelebihan dosis) Admixture tipeD.

\section{Admixture Tipe D}

Dalam percobaan ini, Admixture Tipe D, deskripsi berdasar brosur, material ini berupa cairan yang berfunsi sebagai zat tambah dalam beton yang mampu mengurangi pemakain air bebas dan mampu untuk mengatur setting time beton.

Keunggulan dari tipe D ini antara lain :

1. Meningkatkan setting time beton.

2. Meningkatkan workability beton (kemampuan beton di aplikasikan di lapangan).

3. Meningkatkan mutu beton dengan cara mengurangi air bebas beton.

4. Mengurangi Shrinkage (retak rambut) Pada permukaan beton.

Secara teori admixture tipe adalah bahan kimia tambahan berfungsi ganda yaitu untuk mengurangi air dan memperlambat proses ikatan kimia semen air pada beton.

\section{Macam Penelitian dan Alasan Pemilihan}

Penelitian ini merupakan jenis eksperimen beton, sebagai berikut :

1. Percobaan 1 , beton tanpa admixture tipe $\mathrm{D}$

2. Percobaan 2 , beton dengan dosis admixture tipe D mengikuti brosur dari pabrikan ,

3. Percobaan 3 , beton dengan dosis admixture tipe D lebih dari brosur pabrikan.

4. Percobaan 4 , beton dengan dosis admixture tipe D lebih dari brosur, lebih dari percobaan 3 .

Alasan pemilihan dosis-dosis tersebut diatas adalah Dosis $0 \%$ adalah dosis sebagai parameter rujukan, sedangkan dosis 0,35\% adalah dosis sesuai dengan skala dosis yang ada di brosur Admixture tipe D pabrikan , sedangkan dosis $0,75 \%$ adalah dosis over dari dosis maksimal yang ada di brosur Admixture tipe D pabrikan,

sedangkan dosis $1,10 \%$ adalah teranggap dosis sangat over dari dosis maksimal yang ada di brosur Admixture tipe D pabrikan .

Sedangkan alasan pemilihan dosis $0,35 \%$ yang teranggap dalam skala dosis yang ada di brosur Admixture tipe D pabrikan ( $0,15 \%-0,40 \%$ ) adalah karena dosis tersebut paling banyak digunakan digunakan oleh readymix.

Dalam percobaan ini, Admixture Tipe D yang dipakai adalah Plastiment VZ, deskripsi material ini berdasar brosur dari pabrikan, berupa cairan yang berfungsi sebagai zat tambah beton yang mampu mengurangi pemakaian air bebas dan mampu untuk mengatur setting time beton.

Agar tujuan dalam penelitian ini dapat tercapai sesuai dengan harapan, maka rencana benda uji

yang akan dibuat pada penelitian ini adalah

masing-masing percobaan sebanyak 20 silinder, jadi total benda uji yang terbuat adalah 80 silinder.

\section{Mix Design Percobaan}

Mix design dilakukan untuk mengetahui proporsi kebutuhan material (air, semen, krikil, dan pasir) dalam campuran beton. Metode rancangan beton yang dipakai adalah sebagai berikut :

1. Mutu beton adalah fc30 MPa, Slump10 cm sampai $14 \mathrm{~cm}$

2. Agregat yang dipakai adalah mak 25 $\mathrm{mm}$.

3. Data berat jenis semen $=3,150 \mathrm{Ton} / \mathrm{m}^{3}$

Data berat jenis fly ash $=2,800 \mathrm{Ton} / \mathrm{m}^{3}$ 
Data berat jenis air $\quad=1,000 \mathrm{Ton} / \mathrm{m}^{3}$ Data berat jenis admixture tipeD-VZ = $1,18 \mathrm{Ton} / \mathrm{m}^{3}$

4. Menetapkan rasio water sementitous yaitu sebesar 0,452

5. Menetapkan penggunaan air untuk slump sesuai no. 1 tersebut diatas dengan agregat maksimal $25 \mathrm{~mm}$ ditemukan menjadi $190 \mathrm{~kg} / \mathrm{m}^{3}$.

6. Dari point 5 dan 6 ,maka divcari volume pasta, sebagai berikut kandungan Sementitious adalah $190 / 0,452=420 \mathrm{~kg} / \mathrm{m}^{3}$.

7. Dari jumlah sementitous tersebut , ditetapkan jumlah Fly ash yang dipakai adalah sebesar $48 \mathrm{~kg} / \mathrm{m}^{3}$, dan jumlah semen nya adalah $372 \mathrm{~kg} / \mathrm{m}^{3}$.

8. Ditetapkan kadar udara beton $=1,5 \%$

9. Dari data $6,8,9$, selanjutnya dicari Volume pasta :

Volume semen : $\quad 190 / 1000=$ 0,1950

Volume semen : $\quad 372 / 3150=$ 0,11810

Volume fly ash : $\quad 48 / 2800=$ 0,01714

Volume udara : $\quad 1,5 / 100=$ 0,01500

Volume pasta (semen + fly ash+air+udara $)=0,34024$

Maka volume aggregate adalah $=1$ $0,34024=0,65976$

10. Berdasarkan Fine Modulus pasir sebesar 2,61 dan ukuran maksimum $25 \mathrm{~mm}$ dari agregat kasar , maka ditetapkan kandungan pasir dari jumlah agregat adalah $40 \%$.

11. Dari data no 10 dan data kombinasi grading batu pada table diatas maka , berat jenis gabungan adalah $40 \% *$ Sgpasir $+60 \%((25 \% *$ SGbatu 051 $0)+(75 \% *$ SGbatu 1025)) $=2,704$ ton $/ \mathrm{m} 3$

12. Dosis Admixture tipe D akan dipakai bervariasi yaitu

1. Percobaan $1=$ dosis $0 \%$ dari sementitious

2. Percobaan $2=$ dosis $0,35 \%$ dari sementitious

3. Percobaan $3=$ dosis $0,75 \%$ dari sementitious
4. Percobaan $4=$ dosis $1,1 \%$ dari sementitious

13. Dari data 9,11 dan12, Maka diperoleh mix desain sebagai berikut :

$$
\begin{aligned}
& \text { - Air } \quad: 190 \mathrm{Kg} / \mathrm{m}^{3} \\
& \text { - Semen }: 372 \mathrm{Kg} / \mathrm{m}^{3} \\
& \text { - Fly ash : } 48 \mathrm{Kg} / \mathrm{m}^{3} \\
& \text { - Pasir : } 714 \mathrm{Kg} / \mathrm{m}^{3} \\
& \text { - Batu 0510 : } 267 \mathrm{Kg} / \mathrm{m}^{3} \\
& \text { - Batu } 1025 \text { : } 803 \mathrm{Kg} / \mathrm{m}^{3} \\
& \text { - Tipe D-VZ : (dosis*(semen+fly } \\
& \text { ash))/SG tipe D-VZ } \\
& \text { Percobaan } 1=(0,00 \% \times(372+48)) \\
& / 1,18=0 \mathrm{ltr} / \mathrm{m}^{3} \\
& \text { Percobaan } 2=(0,35 \% \times(372+48)) \\
& / 1,18=1,25 \mathrm{lt} / \mathrm{m}^{3} \\
& \text { Percobaan } 3=(0,75 \% \times(372+48)) \\
& / 1,18=2,67 \mathrm{lt} / \mathrm{m}^{3} \\
& \text { Percobaan } 4=(1,1 \% \times(372+48)) \\
& / 1,18=3,92 \mathrm{lt} / \mathrm{m}^{3}
\end{aligned}
$$

Dalam penelitian ini benda uji yang digunakan silinder dengan diameter $15 \mathrm{~cm}$ dan tinggi $30 \mathrm{~cm}$. Benda uji silinder ini digunakan untuk menguji berapa nilai kuat tekan dari perbandingan komposisi variasi dosis admixture tipeD-VZ.

\section{Diagram Alir Penelitian}

Dalam penelitian ini dilakukan beberapa tahapan penelitian dimulai dari persiapan sampai pengambilan kesimpulan dan saran

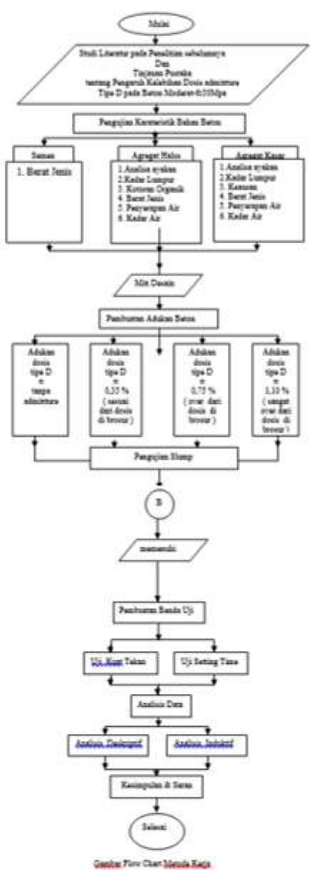




\section{Metode Pengadukan Beton}

Setelah pembuatan komposisi pada Mix Design selesai dilakukan, selanjutnya adalah pembuatan benda uji. Dalam pembuatan benda uji dilakukan beberapa tahapan pembuatan benda uji :

1. Menyiapkan mesin pencampur beton kecil (minipot) untuk membuat benda uji. Dalam proses pencampuran beton semua material dimasukkan kedalam mesin pencampur beton sampai rata, kemudian hasil campuran dapat langsung dimasukkan dalam cetakan yang sudah disiapkan.

2. Menyiapkan cetakan dan member pelumas pada bagian dalam cetakan silinder.

$15 \times 30 \mathrm{~cm}$, cetakan tersebut akan dipakai untuk mencetak benda uji dari campuran adukan beton dari desain yang dibuat untuk penelitian ini.

3. Menimbang material yang digunakan sesuai dengan mix design ,batu, pasir, semen, fly ash, air dan liter admixture tipe $\mathrm{D}-\mathrm{VZ}$, menggunakan pan atau wadah yang sesuai untuk menimbang material/menakar liter an material tersebut.

4. Memasukan dan me-mixing kerikil dan pasir terlebih dahulu kedalam mesin pengaduk beton (minipot).

5. Menimbang air yang akan digunakan sesuai dengan mix design yang direncanakan.

6. Memasukan dan menjadikan satu mixing untuk semen dan fly ash dengan mixing-an batu dan pasir, sampai tercampur dengan rata (Homogen).

7. Setelah semua material tercampur rata kemudian tambahkan air sesuai kebutuhan, lalu mixing lagi hingga rata.

8. Lakukan cek slump secara visual, jika kurang maka tambah air secukupnya sampai dengan slump target tercapai .

9. Tuang beton yang sudah jadi pada gerobak , aduk secara manual, lalu lakukan slump aktual, slump yang didapat catat sebagai data mixing desain beton yang ada .

10. Masukan beton segar kedalam cetakan yang telah disediakan.

11. Setelah 24 jam, cetakan dibuka, kemudian benda uji yang terbuat di kelompokan, dan dirawat dengan cara direndam didalam bak air yang telah disediakan.

\section{Data Uji Percobaan}

Pengujian kuat tekan beton dilakukan saat beton berumur 3 hari , 7 hari , 14 hari , dan 28 hari , dari setiap percobaan yang ada ( percobaan $1,2,3,4$ ). Dengan parameter utama adalah target kuat tekan umur 28 hari , berikut adalah hasil pengujian kuat tekan seperti pada tabel dan grafik dibawah ini :

\section{Kuat tekan 3 hari}

Kuat $\quad$ data tes $\mathbf{3 ~} \mathbf{~ h r}$
Tekan
(Mpa)

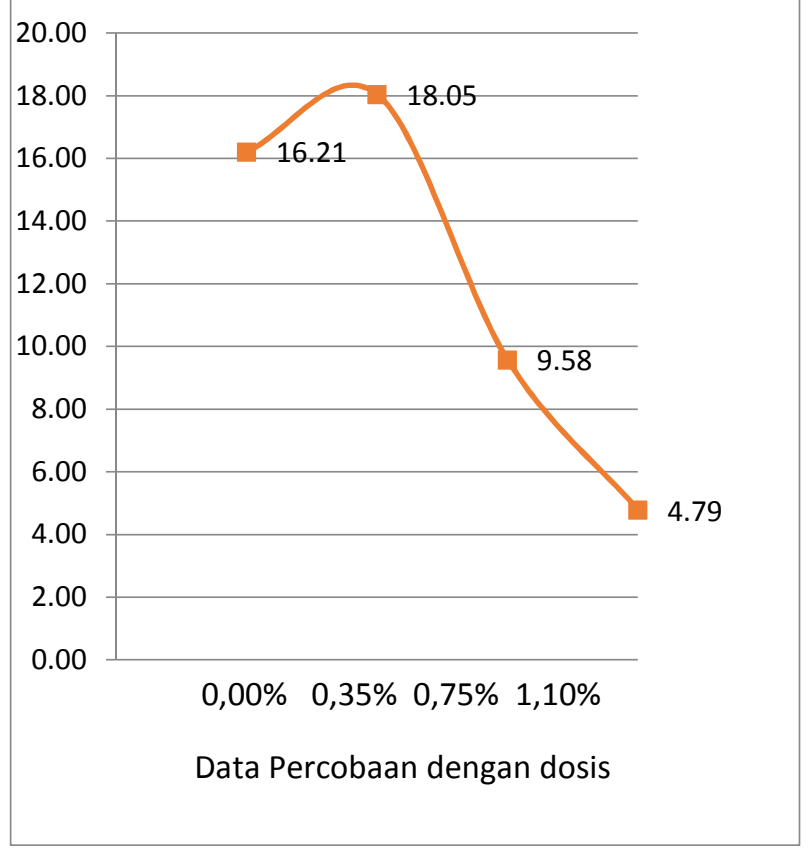

Gambar grafik kuat tekan 3 hari

percobaan admixture tipe $\mathrm{D}$, dengan dosis $0,00 \%$, $0,35 \%, 0,75 \%, 1,10 \%$.

(sumber : olah data) 


\section{Kuat tekan 7 hari}

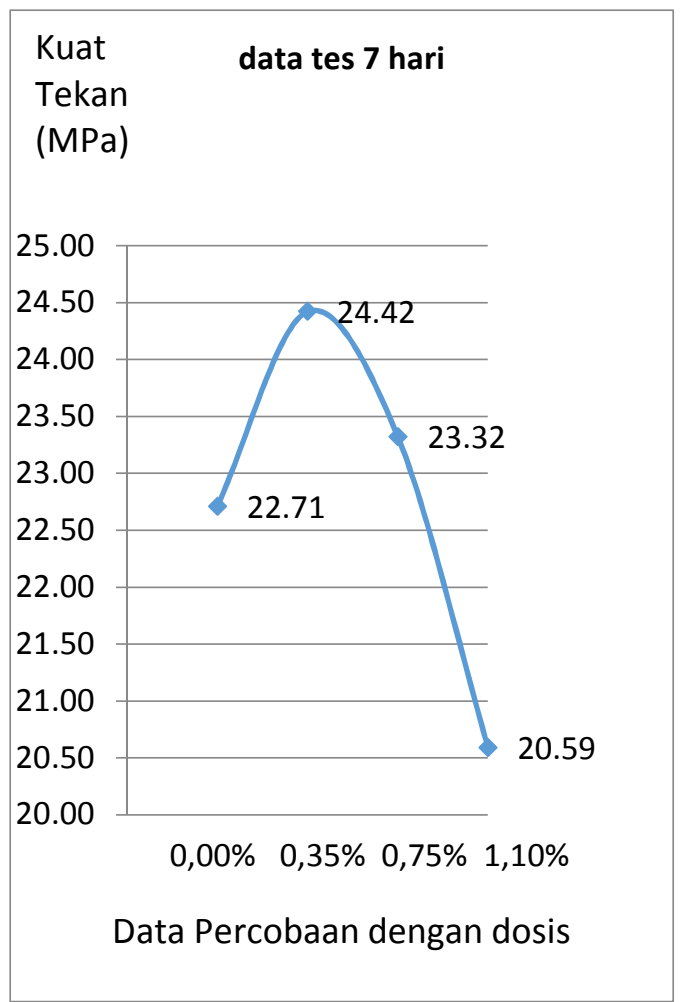

Gambar grafik kuat tekan 7 hari percobaan admixture tipe $\mathrm{D}$, dengan dosis $0,00 \%$, $0,35 \%, 0,75 \%, 1,10 \%$.

(sumber : olah data)

\section{Kuat tekan 14 hari}

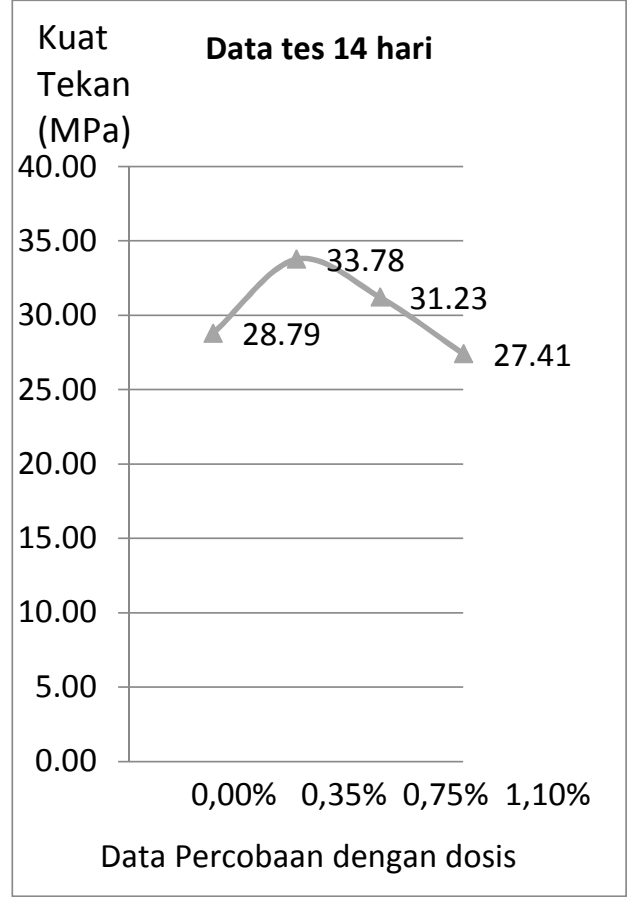

Gambar grafik kuat tekan 14 hari percobaan admixture tipe $\mathrm{D}$, dengan dosis $0,00 \%, 0,35 \%$, $0,75 \%, 1,10 \%$. (sumber : olah data)

\section{Kuat tekan 28 hari}

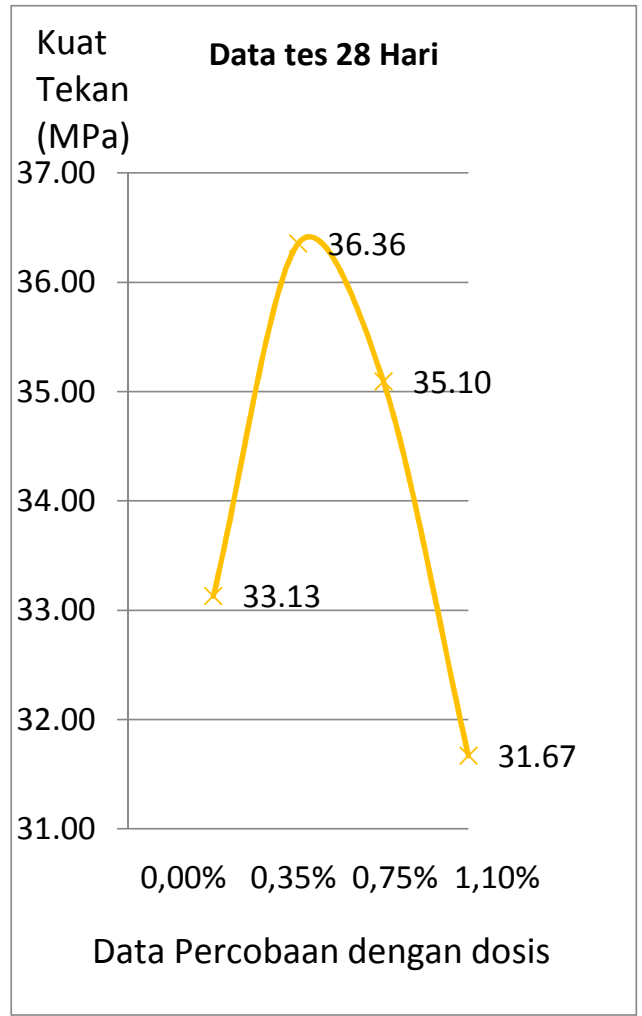

Gambar grafik kuat tekan 28 hari percobaan admixture tipe $\mathrm{D}$, dengan dosis $0,00 \%, 0,35 \%$, $0,75 \%, 1,10 \%$.

(sumber : olah data)

Hasil Percobaan 1,2,3,dan 4 untuk tes Initial Sett nya

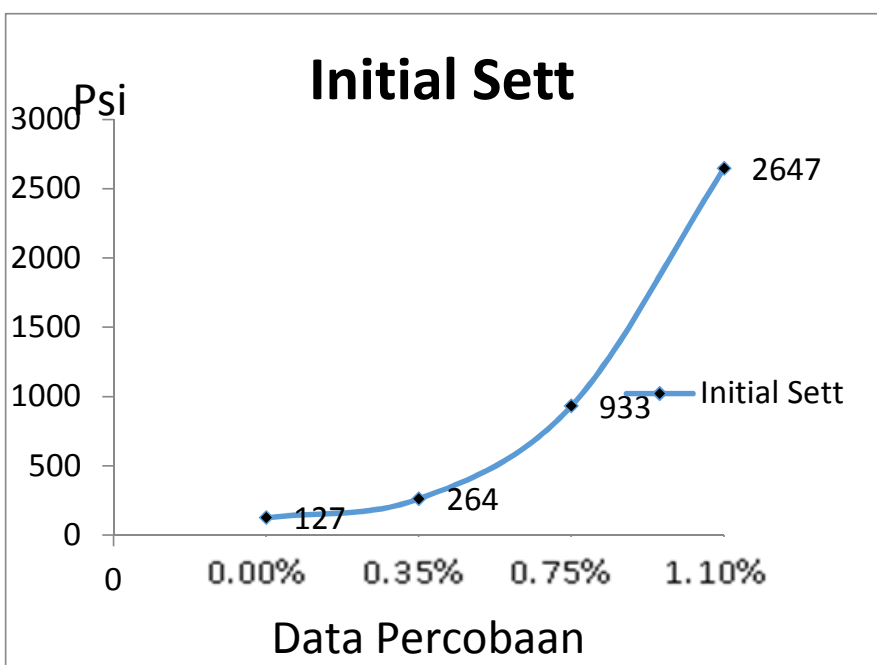

Grafik Initial Sett percobaan dengan dosis tanpa admixture tipe $\mathrm{D}$ dengan dosis $0,35 \%, 0,75 \%, 1,10 \%$. 
Dari gambar grafik tersebut untuk desain percobaan 1 tanpa admixture tipe D-VZ, dosis $0,00 \%$, intial settnya adalah 127 menit atau 2 jam 7 menit, sedangkan untuk desain percobaan 2 admixture tipe D-VZ, dosis $0,35 \%$, intial settnya adalah 264 menit atau 4 jam 24 menit, sedangkan untuk desain percobaan 3 admixture tipe D-VZ, dosis $0,75 \%$, intial settnya adalah 933 menit atau 15 jam 33 menit, sedangkan untuk desain percobaan 4 admixture tipe $\mathrm{D}-\mathrm{VZ}$, dosis $1,10 \%$, intial settnya adalah 2647 menit atau44 jam 7 menit

Hasil Percobaan 1,2,3,dan 4 untuk tes Final Sett nya

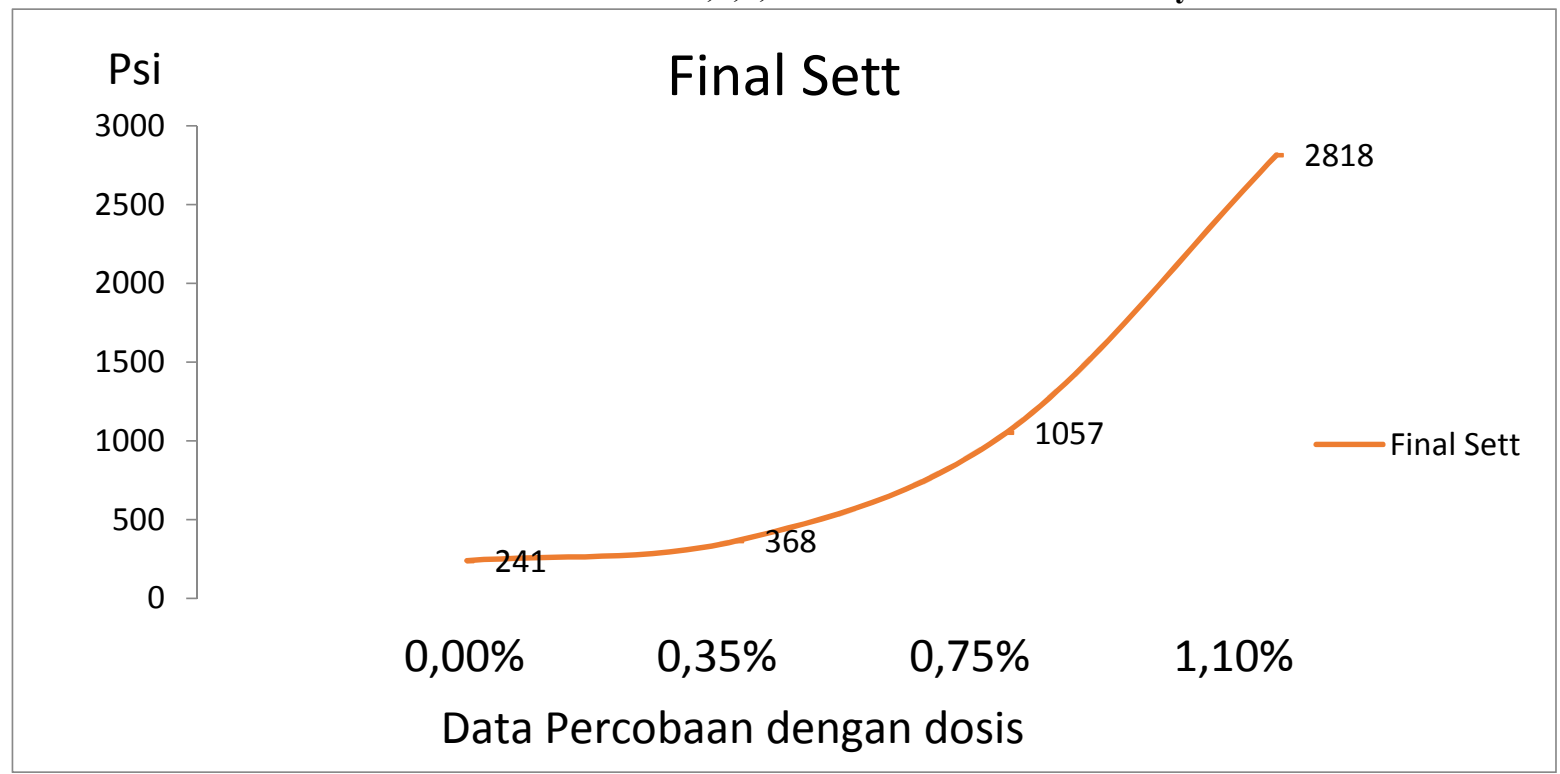

Grafik Final Sett percobaan dengan dosis tanpa admixture tipe D, dengan dosis $0,35 \%, 0,75 \%, 1,10 \%$.

Dari gambar grafik tersebut diatas, Untuk desain percobaan 1 tanpa admixture tipe D-VZ, dosis 0,00\%, intial sett nya adalah 241 menit atau4 jam1 menit, sedangkan untuk desain percobaan 2 tanpa admixture tipe D-VZ, dosis $0,35 \%$, intial sett nya adalah 368 menit atau 6 jam 8 menit ,sedangkan untuk desain percobaan 3 tanpa admixture tipe D-VZ,

dosis $0,75 \%$, intial settnya adalah 1057 menit atau 17 jam 37 menit ,sedangkan untuk desain percobaan 4 tanpa admixture tipe D-VZ, dosis 1,10\%, intial sett nya adalah 2818 menit atau 46 jam 58 menit

\section{KESIMPULAN}

Sesuai dengan rumusan masalah studi yaitu bagaimana desain proporsi campuran beton dengan menggunakan variasi dosis admixture tipe $\mathrm{D}$ dan bagaimana pengaruh dosis admixture tipe D pada kuat tekan dan setting time beton yang ada . Dari hasil studi dan pengolahan data yang telah dilakukan pada bab sebelumnya, dapat diperoleh kesimpulan yaitu sebagai berikut :

1. Terkait kuat tekan Beton

Secara umum acuan kuat tekan beton adalah pada umur 28 hari, prosentase dosis optimum yang menghasilkan kuat tekan terbaik dari percobaan variasi dosis tersebut adalah pada prosentase dosis $0,35 \%$.

Dan untuk dosis 1,1\%, kuat tekan fc $30 \mathrm{MPa}$ masih bisa tercapai

2. Terkait waktu untuk Setting Time

$$
\text { a. Terkait Inisial Sett }
$$

Pemakian dan Penambahan dosis admixture tipe D-VZ pada beton, ternyata berdampak pada proses pengerasan beton (adanya perlambatan pengersasan beton ), dengan parameter beton non penambahan admixture tipe D-VZ, percobaan 1 dengan dosis $0,00 \%$ menghasilkan inisial sett sebesar 127 menit, data perlambatan pengersaan pada percobaan 2,3 dan 4 sebagai berikut : Untuk desain percobaan 2 dengan admixture tipe D-VZ, dosis $0,35 \%$, data inisial sett nya 267 menit, jadi mengalami lebih lambat untuk waktu inisial sett nya sebesar 137 menit atau lebih lambat 2 jam 17 menit dari inisial sett percobaan 1. Untuk desain percobaan 3 dengan admixture tipe $\mathrm{D}-\mathrm{VZ}$, dosis $0,75 \%$ , data inisial sett nya 933 menit, jadi mengalami lebih lambat untuk waktu insial sett nya sebesar 806 menit atau lebih lambat 13 jam 26 menit dari inisial sett percobaan 1. Untuk desain percobaan 4 dengan admixture tipe D-VZ, dosis $1,10 \%$, data inisial sett nya adalah 2647 menit, jadi mengalami waktu lebih lambat untuk waktu inisial sett nya 2520 menit atau lebih lambat 42 jam 0 menit atau lebih lambat 1 hari 18 jam 0 menit dari inisial sett percobaan 1 .

\section{b.Terkait Final Sett}

Dengan parameter beton non penambahan admixture tipe D-VZ, percobaan 1 dengan dosis 0,00\% menghasilkan Final sett sebesar 241 menit, data perlambatan pengersaan pada percobaan 2,3 dan 4 sebagai berikut : 
Untuk desain percobaan 2 dengan admixture tipe D-VZ, dosis $0,35 \%$, data final sett nya adalah 368 menit, jadi mengalami waktu lebih lambat untuk waktu final sett nya sebesar 127 menit atau atau lebih lambat 2 jam 7 menit dari waktu final sett percobaan 1. Untuk desain percobaan 3 dengan admixture tipe D-VZ, dosis $0,75 \%$ , data final sett nya adalah 1057 menit, jadi mengalami waktu lebih lambat untuk waktu final sett nya sebesar 816 menit atau lebih lambat 13 jam 36 menit dari waktu final sett percobaan 1 . Untuk desain percobaan 4 dengan admixture tipe D-VZ, dosis $1,10 \%$, data final sett nya adalaha 2818 menit, jadi mengalami lebih lambat untuk waktu final sett nya sebesar 2577 menit atau lebih lambat 42 jam 57 menit atau lebih lambat 1 hari 18 jam 57 menitdari waktu final sett percobaan 1 .

3. Berdasar SNI Beton 2013 , evaluasi dari beton dengan kuat tekan sesuai kuat tekan rencana adalah lulus

\section{Saran}

Dari kesimpulan yang di peroleh, maka dapat diberikan saran yaitu sebagai berikut :

1. Bahwa desain dengan penambahan admixture tipe D-VZ akan menghasilkan kuat tekan lebih besar dari desain tanpa admixture tipe D-VZ , jika memakai dosis draft pada brosur admixture tipe D tersebut , kuat tekan paling optimum adalah $0,35 \%$.

2. Untuk kondisi khusus, proyek yang jauh daripabrik readymix dan readymix tersebut truk mixer nya dengan jumlah sedikit, sehingga interval beton lama dengan beton baru sangat jauh(lama), maka pilihan over dosis dari dosis draft brosur adalah salah satu solusi agar beton baru dengan beton lama masih monolit tidak cold joint (= sambungan beton yang tidak menyatu dengan beton sebelumnya).

3. Untuk praktisi beton baik kontraktor, ataupun konsultan pengawas proyek, lebih baik mempunyai data valid (lebih bagus kalau dari trial sendiri), bahwa kasus beton long setting yang dikarenakan over dosis admixture tipe DVZ, mempunyai kuat tekan 28 hari yang juga tercapai kuat tekan rencana.

4. Berdasar SNI beton 2847:2013, jika merasa ragu terhadap beton yang terpasang, maka bisa dilakukan dengan tes lapangan yaitu core drill ( pengambilan beton pada struktur beton yang terpasang dengan cara di lubangi) , sebagai catatan pengujian lapangan metrode Hamer Tes hanya dipakai untuk mengetahui nilai keseragaman beton saja, tidak bisa dijadikan parameter pada mutu beton terpasang.

\section{DAFTAR PUSTAKA}

ASTM Standard C33. (2006). "Specification for Concrete Aggregates".

ASTM Standard C143. (2005). Standard Test Method for Slump ofHydraulics Cement Concrete.

ASTM Standard C642. (2006). "Standard Test Method for Density, Absorption, and Voids in Hardened Concrete". West Conshocken

Badan Standardisasi Nasional. 2002. "Tata Cara Perhitungan Struktur Beton Untuk Bangunan Gedung”.SNI 03-2847-2002. Bandung: Departemen Pekerjaan Umum

Badan Standardisasi Nasional. 2002. "Spesifikasi Abu Terbang dan Pozzolan lainnya untuk digunakan dengan kapur." SNI 06-6867-2002. Jakarta: Departemen Pekerjaan Umum

Badan Standarisasi Nasional. 2004, "Semen Portland", SNI 15-2049-2004. Jakarta:DepartemenPekerjaan Umum

Badan Standardisasi Nasional. 2008. Cara Uji Berat Jenis dan Penyerapan AirAgregat Halus. Jakarta: Departemen PU

Badan Standardisasi Nasional. 2013. "Persyaratan beton struktural untuk bangunan gedung”. SNI 032847-2013. Jakarta: DepartemenPekerjaan Umum

Departemen Pekerjaan Umum. 2002, "Tata Cara Perhitungan Struktur Beton Untuk Bangunan Gedung”, SNI 03 - 2847 - 2002. Bandung: BSN

Mulyono, Tri (2005). “Teknologi Beton”. Yogyakarta: Andi Offset

PBI, 1971. "Peraturan Beton Bertulang Indonesia". Direktorat Penyelidikan Masalah Bangunan. Bandung

Samekto, Wuryati. dan Rahmadiyanto, Candra. (2001).

"Teknologi Beton." Yogyakarta

Kanisius.Sutikno. (2010), “Teknologi Beton.” Teknik Sipil Universitas Negeri Surabaya

Sri Murni Dewi , Lutfi Djakfar , 2008 , " Statistika Dasar", untuk tehnik sipil

Djarwanto Ps , Pangestu Subagyo , Edisi ke 4,(1993)"Statistika Induktif " Dosen Univ. Sebelas Maret Solo dan Dosen Univ. Gajah Mada Syofan Siregar , (2010), " Statistika deskriptif untuk Penelitian"

Paul Nugraha , Antoni . (2007). " Teknologi Beton dari Material , Pembuatan, Beton Kinerja Tinggi " Yogyakarta Universitas Kristen Petra. 